\title{
Development of small hydroenergy in Ukraine and its legal regulation
}

\author{
Mykola Misiuk ${ }^{1}$, Tetiana Podorozhna ${ }^{2}$, Olha Balynska ${ }^{3}$, Oleg Kucher ${ }^{1, *}$, \\ Oleksandr Burlakov ${ }^{1}$ \\ ${ }^{1}$ State Agrarian and Engineering University in Podillia, Kamianets-Podilskyi, Ukraine \\ ${ }^{2}$ Yuriy Fedkovych Chernivtsi National University, Ukraine \\ ${ }^{3}$ Lviv State University of Internal Affairs, Ukraine
}

\begin{abstract}
The state and prospects of small hydropower development in the context of rationalization of the use of available natural resource potential of Ukraine were considered. It was established that due to insignificant specific weight in the general energy balance, small hydropower cannot significantly affect the structure of energy supply of the country. Attention was drawn to the fact that the adopted State Target Economic Program for Energy Efficiency and the Development of Energy Saving for Renewable Energy Sources and Alternative Fuels for 2010-2020 will promote the use of the potential of small rivers and the development of hydropower. It was noted that the conducted calculations for the future with the help of correlation analysis of installed capacities and production of electricity by small hydropower objects showed that in 2020, at the current rate of development of small hydropower, the planned indicators will not be achieved. The legal principles of functioning of the market of electric energy and formation of relations connected with the development of small hydropower, which are regulated by the Laws of Ukraine and other legislative acts in the field of fuel and energy complex were described.
\end{abstract}

\section{Introduction}

The use of renewable energy sources today is an important direction for the development of Ukraine's energy sector. On the one hand, the level of security of its own primary energy sources does not allow speaking about the energy independence of the country, and on the other hand, Ukraine has a large hydropotential of small rivers. Hydropower is one of the pillars of renewable energy worldwide.

Ukraine has powerful hydro energy resources for the small rivers. The total hydropower potential of Ukraine's small year is about 12.5 billion $\mathrm{kWh}$, which is almost $28 \%$ of the total hydropotential of all year Ukraine. The main advantage of small hydropower is the cheapness of electricity generated by hydroelectric power plants, the lack of a fuel component in the process of generating electricity and the positive economic effect.

\footnotetext{
* Corresponding author: kucheroleg68@gmail.com
} 


\section{Methodology and purpose of the study}

In the process of this scientific study, the following methodological approaches were used:

- an analysis of the diversification of sources of energy supply, in particular, the increase of the share of energy produced from RES in the overall structure of energy consumption of the state, was conducted.

To present the results of the study were used:

1. Table, graphic, calculation methods, which allowed to analyze the dynamics of development of small hydropower for the period 2013-2017 years.

2. The forecasting method allowed, using the correlation analysis, to calculate the forecast indicators for the development of energy production by small hydroelectric power stations for 2018-2020 years.

The purpose of the study was to assess the state of development of small hydropower in Ukraine and the prospects for its use in the energy supply system of the country.

\section{Research results}

\subsection{The current state of small hydropower development in Ukraine}

The use of water for energy purposes has been used by humankind for a long time. The origin of hydropower in Ukraine took place in the late XIX - early XX century. During its existence, the hydroelectric power of Ukraine has undergone several stages of formation, each of which played a different role in the energy system of the country.

The vast majority of existing hydroelectric power plants in Ukraine are power plants of high capacity with their own reservoirs, located mainly in the riverbank of the Dnipro and Dniester rivers. Some stations use their reservoirs in conjunction with hydroaccumulation stations. However, a significant part of all hydroelectric power plants in Ukraine falls on small hydroelectric plants for which, at the state level, it has been established the stimulation of the development of electricity production using the "green" tariff. In accordance with the existing classification, small hydroelectric power stations include hydroelectric power stations with capacity from 1 to $10 \mathrm{MW}$, to mini-HEPS - from 200 to $1000 \mathrm{~kW}$, to microHEPS - no more than $200 \mathrm{~kW}$ [3].

On the territory of Ukraine there are more than 63 thousand small years and streams with a total length of 135.8 thousand $\mathrm{km}$, of which about 60 thousand $(95 \%)$ are very small and have a length of less than $10 \mathrm{~km}$. The total length of these rivers is 112 thousand $\mathrm{km}$. The main hydro power resources are concentrated on small rivers, mainly in the Carpathian region, which includes Zakarpatska, Lviv, Ivano-Frankivsk and Chernivtsi regions [1].

The modern world faces a huge energy crisis, which associates with exhaustion of conventional energy resources. Therefore, power generation getting from alternative sources increasingly attracts both scientists and businessmen [17].

The Institute of Renewable Energy of the National Academy of Sciences of Ukraine created the Atlas of Energy Potential for Renewable Energy Sources of Ukraine, which presents the annual technically feasible renewable energy potential of the country. According to indicators given in the Atlas, the annual technically feasible potential of small hydropower is 8.6 billion $\mathrm{kWh}$ / year, with the use of which the electricity generation will be 2.1 million tons of nuclear energy per year [4].

Getting energy from small hydroelectric power plants in the world is one of the types of renewable energy. Europeans are actively developing this type of generation, as this is a relatively cheap way to get the net energy that can be used to balance other capacities. Today in most developed countries of the world a high level of development of small hydropower 
resources is achieved. Western Europe has absorbed $85 \%$ of its small hydropower potential, which is the highest in the world. Countries such as Austria, France and Germany have already mastered a significant proportion of their potential. The total installed capacity of the small HEP in Western Europe is $6183 \mathrm{MW}$, and the potential is estimated at $7243 \mathrm{MW}$ [3].

Analyzing the state of small hydropower development in Ukraine it should be noted that for the period of 2013-2017, the number of objects and subjects of small hydropower industry is characterized by a stable increase. Most small hydroelectric power plants were put into operation in Vinnytsia region, the total installed capacity of which is about 21.9 MW. The following installed capacity is Kirovograd, Zakarpatska and Ternopil regions. The largest number of operating under the "green" tariff of the small HEPS is located in the Khmelnytsky and Vinnytsia regions. There are 50 power plants here, which is $37.5 \%$ of the total number of power plants in Ukraine [1].

According to the National Commission for State regulation in the energy and utilities sectors, at the beginning of 2018, 136 small hydroelectric plants were registered, which is $51.1 \%$ more than the value of 2013 . The number of business entities grew by $71.4 \%$ at the "green" tariff. Total capacity during this period increased by $25.6 \%$. At the same time, the amount of electricity produced by small hydropower projects in 2017 compared to 2013 decreased by $25.7 \%$ and amounted to 212.5 million $\mathrm{kWh}$. Capacity utilization in 2017 is only $59.1 \%$ compared to 2013 . As a result, the utilization rates of installed capacity decreased from $43.4 \%$ in 2013 to $25.6 \%$ in 2017 (Table 1).

Table 1. Dynamics of the number of small hydropower objects and the use of installed capacity for the period 2013-2017.

\begin{tabular}{|l|c|c|c|c|c|}
\hline \multicolumn{1}{|c|}{ Indicators } & $\mathbf{2 0 1 3}$ & $\mathbf{2 0 1 4}$ & $\mathbf{2 0 1 5}$ & $\mathbf{2 0 1 6}$ & $\mathbf{2 0 1 7}$ \\
\hline Number of objects of small hydropower, units & 90 & 102 & 114 & 125 & 136 \\
\hline Number of business entities, units & 35 & 40 & 48 & 52 & 60 \\
\hline Installed capacity, MW & 75,3 & 80,2 & 86,9 & 90,0 & 94,6 \\
\hline Electricity production, million kWh & 286,0 & 250,7 & 171,6 & 189,3 & 212,5 \\
\hline Time of use, year in year & 3798 & 3126 & 1975 & 2103 & 2246 \\
\hline Capacity utilization factor,\% & 43,4 & 35,7 & 22,5 & 24,0 & 25,6 \\
\hline
\end{tabular}

Calculations were based on data $[5,6,7]$.

Among the objects of RES, the greatest success was achieved in the implementation of small hydropower projects. Planned capacity indicators for the period 2014-2017 yearly increased on average by $10 \mathrm{MW}$. In 2017 it was planned to bring the capacity of small hydroelectric power stations to $117 \mathrm{MW}$, which is $29 \mathrm{MW}$ more than in 2014, and actually the installed capacity during this period increased by only 14.4 MW. This indicates that the planned level of installed capacity was not achieved (Fig. 1).

Planned growth of electricity production during 2014-2017 is 65 GWh. However, the actual implementation of the planned targets did not ensure the planned level, since growth was only $17.5 \mathrm{GWh}$ (Fig. 2).

The planned capacity utilization rate in 2014 was $88 \mathrm{MW}$ and was executed at $91.1 \%$, and in 2017 the actual installed capacity was $117 \mathrm{MW}$, and execution was only $80.9 \%$ of the target. A slightly different situation regarding the implementation of the plan for the production of electricity. In 2014, the electricity production plan was $195 \mathrm{GWh}$, and it was overfilled by $28.6 \%$, and in subsequent years the proven plans were not implemented and in 2017 the implementation of the proven indicator was $81.7 \%$ (Fig. 3). 


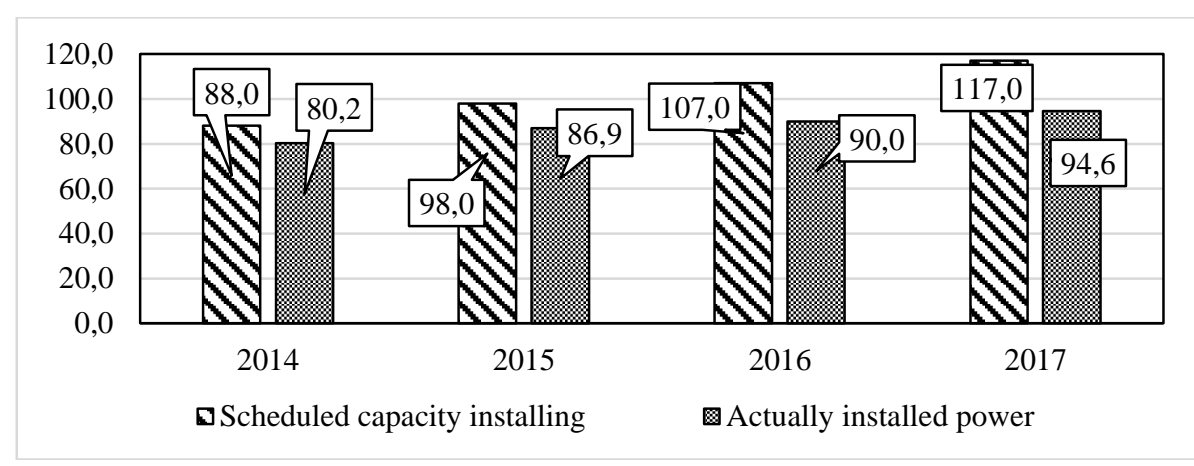

Fig. 1. Dynamics of installation of capacity of small hydropower objects, MW. Source $[1,5,7]$

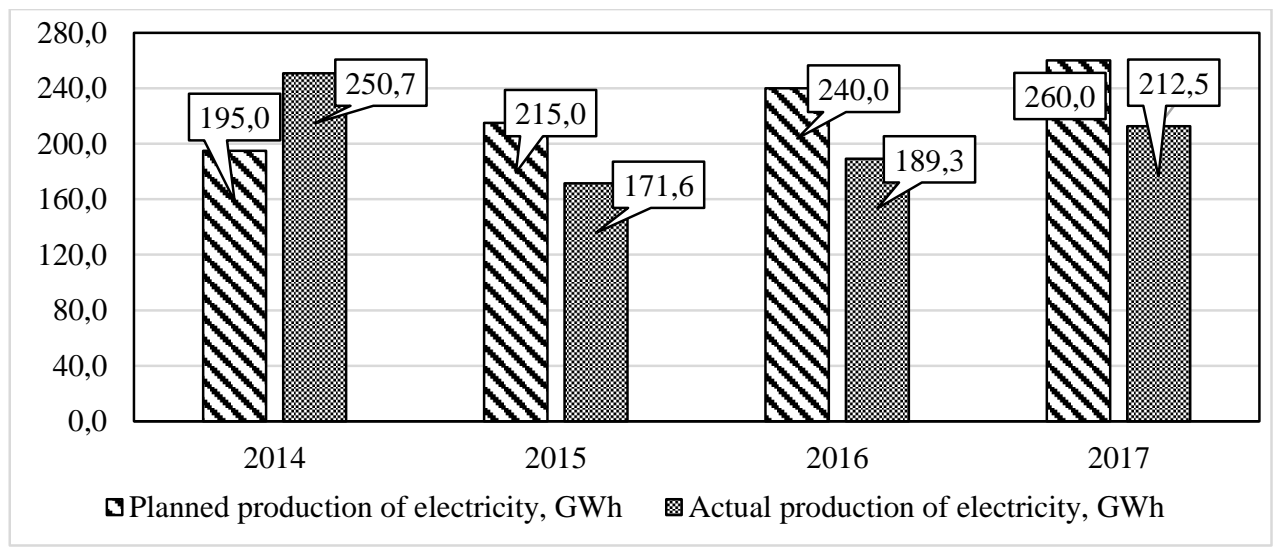

Fig. 2. Dynamics of electricity production facilities of small hydro power, GWh. Source $[2,5,7]$.

The results of the conducted research indicate that the planned indicators for installed capacity and electricity production are not met. However, at present, the operation of small hydropower plants makes it possible to produce about 213 million kilowatt-hours, however, the natural potential of its development is not yet fully realized.

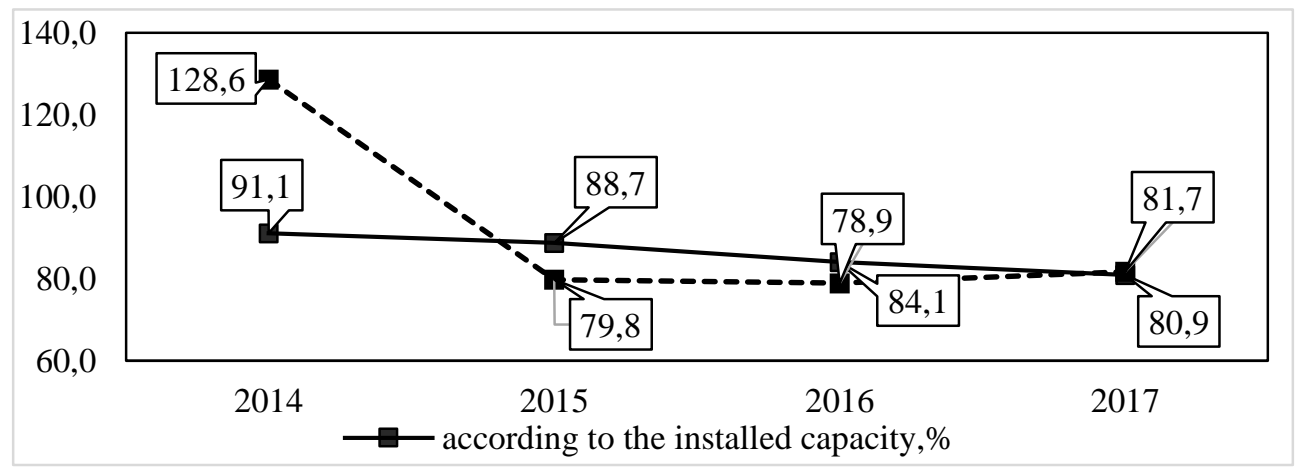

Fig. 3. Implementation of the plan for installed capacity and electricity production, $\%$

Calculations were based on Table 1 data.

In total, 136 small HEPS were built in Ukraine. Their total capacity is only $0.094 \mathrm{GW}$. At present, 83 thousand of power plants operate in 150 countries of the world, supplying 
about 13 million households with electricity. Using hydropower in these countries avoids 29 million tonnes of $\mathrm{CO}^{2}$ emissions. Thus, in Germany there are 7,500 small hydropower plants with a combined capacity of $1.6 \mathrm{GW}$ in Austria, they reach 2590 and have a capacity of 1.2 GW, in Sweden and France, 1900 GWPs with a capacity of 2 and 1.2 GW respectively [8].

Still nowadays, Norway is a benchmark of using hydropower remains - one of the richest country in the world. Hydropower provided the basis for industrialization of the nation at the end of the 19th century and remains the basis of the country's energy system, since it produces more than $95 \%$ of Norwegian energy. Since 2003, more than 350 small hydropower plants have been commissioned in the country, and their number is expected to grow significantly by 2020 . In addition, in 2016, using a record production of hydropower, Norwegian exports of clean electricity reached 16.5 billion $\mathrm{kWh}$, which is about $10 \%$ of total domestic production [9].

Ukraine, in the field of renewable energy, has a strong hydropower resources of a small rivers, which is about 63 thousand. Their potential amounts to $28 \%$ of Ukraine's overall hydropotential. The development of small hydropower provides an opportunity to solve energy supply problems in remote rural areas, in particular Western Ukraine, where micro and mini hydroelectric power stations could become the basis for their energy supply [10].

The further development of small hydropower engineering in Ukraine requires the reconstruction and technical improvement of hydro-units. The replacement of physically obsolete equipment should be carried out at the current level using automation and computerization tools. New small hydropower facilities can potentially be located in any region with small or large rivers. The advantages of small hydropower are:

- significant service life and high reliability of operation;

- electricity production without the use of fossil organic and nuclear fuel;

- predictability and security of working regimes;

- high ratio of maneuverability and readiness ;

- the possibility of complete automation of the operation process;

- minimal environmental impact, with the right choice of location and compliance with environmental legislation;

- minimal impact on the landscape and minor alienation of land plots;

- Additional opportunities for fishing, irrigation, water supply [11].

With the full utilization of the hydropotential of small rivers in Ukraine, a significant saving in fuel and energy resources can be achieved, and the development of small hydropower will contribute to the decentralization of the overall energy system, which will enable to solve a number of problems in the supply of remote and hard-to-reach areas of the countryside.

\subsection{Potential of the development of small hydropower energy}

In recent years, Ukraine has been following world trends and developing clean energy. To produce this new type of product, there are the necessary resources and sufficient potential. Ukraine is included in the country's ranking on the attractiveness of alternative energy development published by Ernst \& Young. The company's research notes that Ukraine has great potential for the development of renewable energy sources, and with the new "Green Tariff" Law adopted in 2009 and favorable economic conditions of renewable energy investments. Ukraine has significant resources for its development, including rivers with a powerful hydrological energy reserve. Developing the potential of small rivers using small hydroelectric power stations helps to solve the problem of improving energy supply to consumers [12].

At the All-Ukrainian forum on mini hydroelectric power plants, scientists noted that Ukraine is lagging behind not only leaders in Europe for the construction of the small HEPS 
of Norway, France, Italy, but also countries such as Georgia, Poland and others. Attention is drawn to the fact that Zakarpatya, which has $36 \%$ of the total Ukrainian potential, has a very small number of small hydroelectric power stations. Zakarpatya can make the largest contribution to the implementation of the Energy Strategy of Ukraine on the development of small hydropower, taking into account the greatest potential available. Scientists can help implement investment projects by pointing out the best options for solving the problem issues regarding the environmental impact of newly created small HEPS and improving existing ones [13].

According to the International Renewable Energy Agency (IRENA), the overall hydropower potential of Ukraine's small rivers is 12.5 billion $\mathrm{kWh} /$ year, or 3.05 million tons. e. / year, technically achievable hydropower potential is 8.6 billion $\mathrm{kWh} /$ year, or 2.1 million tons n. e. / year. It can be used both in the regional centers, and in the remote, hardaccessible areas [4].

In order to ensure the use of the potential of small rivers and the development of hydropower, the State Target Economic Program for Energy Efficiency and the Development of the Energy Sources for Renewable Energy Sources and Alternative Fuels for 2010-2020 was adopted, which was approved by the Resolution of the Cabinet of Ministers of Ukraine dated 01.03.2010 No. 243.

According to the program, it is planned:

- restoration of small hydropower and construction of new facilities;

- conducting research on the potential of regions for the allocation of renewable energy facilities;

- conducting surveys of the current state of small hydroelectric power stations [14].

The current capacity of small hydropower projects is about 95 MW. (see Table 1). According to the National Renewable Energy Action Plan for the period up to 2020, due to the modernization of existing capacities, the restoration of old small hydroelectric power plants, the construction and commissioning of new generating capacities of hydropower up to $150 \mathrm{MW}$, it is possible to provide electricity production in 2020 up to $340 \mathrm{GWh}$, which corresponds to 30 thousand tons of oil equivalent. In particular, micro and mini-HEPS - up to $130 \mathrm{GWh}$ with a total capacity of $55 \mathrm{MW}$, and small hydropower plants up to $210 \mathrm{GWh}$ with a total capacity of 95 MW [15].

According to the conducted research of the state of installation of capacities and production of electric power by objects of small hydropower for the period of 2013-2017 (see Table 1), the forecast of the potential of development of this sector of the electric power industry for the period up to 2020 (Figure 4, 5).

Increase in the capacity installed by objects of small hydropower is characterized by a straight line equation.

$$
y=4,84 x+70
$$

On the received graph of the linear trend, $\mathrm{R}^{2}=0.988$, which classifies the connection between the values as high, and the constructed model is adequate to the real data. The regression coefficient of the above equation shows that the average annual growth of the capacity installed by the objects of small hydropower will be $4.84 \mathrm{MW}$. The high value of the determination coefficient of this equation gives reason to trust this forecast. In case of saving of the dynamics of the conditions of influence on the development of small hydropower, taking into account purely mathematical criteria of behavior of the indicator of installed capacity of small hydro power objects in five years, one can expect an increase to $110 \mathrm{MW}$ in 2020, which is $73.3 \%$ of the planned in National Action Plan.

The tendency of the dynamics of electricity production by objects of small hydropower is characterized by a straight line equation and has the form: 


$$
y=-20,84 x+284,54
$$

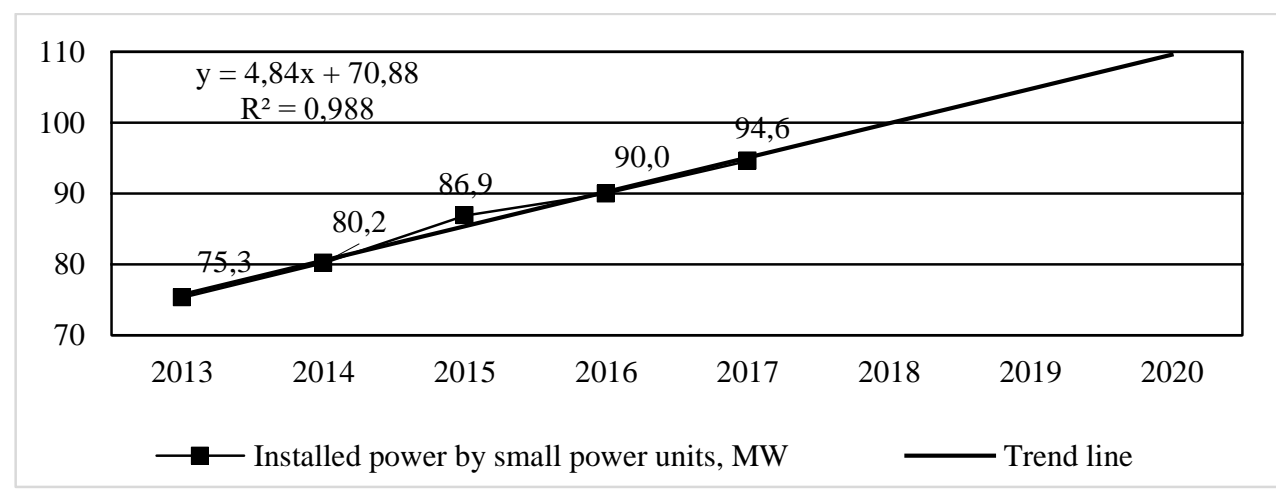

Fig. 4. Analytical leveling of the dynamics of the installed capacities of objects of small hydropower in Ukraine, MW 2013-2020.

Source: Data is based on [Table. 1].

The regression coefficient in the above equation shows that the average annual reduction of electricity generation by small hydro power plants is 20.84 million $\mathrm{kWh}$. At the same time, the determination coefficient is 0.5039 , indicating that the model is in line with the data and the degree of confidence in the forecast drawn up by the linear trend may be acceptable. Based on the results of the analytical equalization of electricity production by small hydroelectric power plants and equation 3.2, it can be assumed that by 2020 electricity production will approach 117.82 million $\mathrm{kWh}$. This indicator is $34.7 \%$ of the planned National Action Plan.

Calculations made regarding installed capacities and production of electricity by small hydropower objects showed that in 2020, under the current rates of development of small hydropower, the planned targets will not be achieved (Table 2).

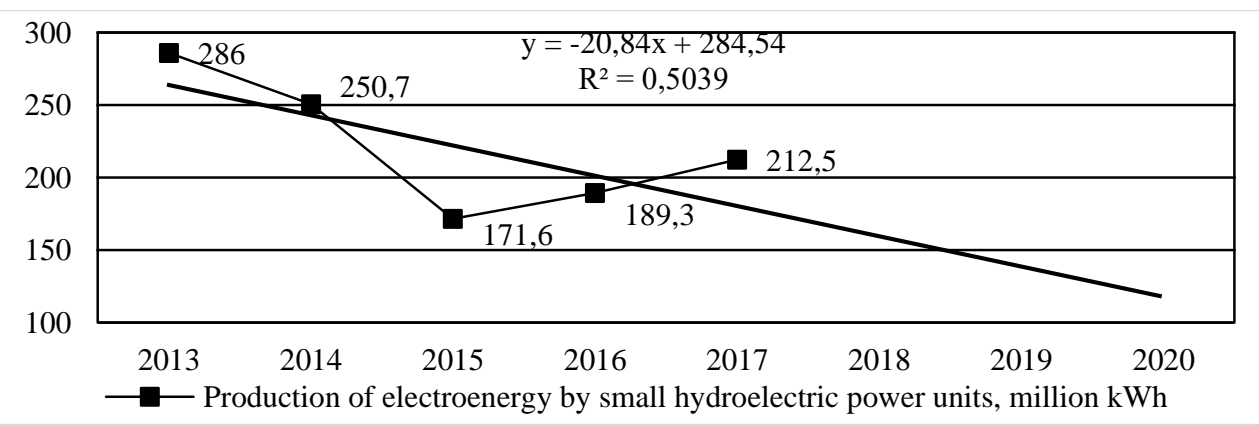

Fig. 5. Analytical equalization of the dynamics of electricity production by small hydropower objects, million kWh 2013-2017

Source: Data is based on [Table 1].

To ensure these indicators in the National Action Plan, the order of the Cabinet of Ministers of Ukraine dated 10/01/2014, No. 902-p, the relevant Action Plan for the implementation of the National Action Plan for Renewable Energy for the period up to 2020 was approved. The plan states that, in order to implement measures for the implementation of the National Action Plan, the estimated amount of funding will be 2914000 thousand hryvnias. Sources of funding will be the funds of investors or attracted credit resources. The departments of the State Department of Economic Development, the Ministry of Economic 
Development and the Ministry of Energy and Coal Industry are responsible for the implementation of this Action Plan [15].

It should be noted that in order to solve the issues of small hydropower development, Ukraine has sufficient scientific and technical capabilities and considerable experience in the field of hydropower potential research, hydroelectric power plant design, designing and production of hydro turbine and electric equipment, and solving water and environmental problems in the construction and operation of hydroelectric power stations.

Table 2. Development of small hydropower according to the National Action Plan and according to the linear trend.

\begin{tabular}{|c|l|c|c|c|}
\hline \multicolumn{2}{|c|}{ Indicators } & $\mathbf{2 0 1 8}$ & $\mathbf{2 0 1 9}$ & $\mathbf{2 0 2 0}$ \\
\hline 1 & Planned installed power, MW & 127 & 138 & 150 \\
\hline 2 & In fact, available installed capacity for linear trend, MW & 99,9 & 104,8 & 109,6 \\
\hline 3 & Planned production of electricity, GWh & 285 & 310 & 340 \\
\hline 4 & $\begin{array}{l}\text { In fact, the possible production of electricity, according to } \\
\text { the linear trend GWh }\end{array}$ & 159,5 & 138,7 & 117,8 \\
\hline
\end{tabular}

Sources: [16 Annex 6, Fig. 4, 5]

The country has a developed domestic machine-building complex for the production of equipment for both reconstruction and rehabilitation, as well as for the construction of hydroelectric power stations of various sizes [4].

Development of small hydropower of Ukraine provides:

- renovation and reconstruction of existing and operating small hydroelectric plants;

- construction of new small hydropower plants in areas of decentralized energy supply;

- construction of small hydroelectric power stations in the regions of centralized energy supply at existing differences in reservoirs and watercourses;

- new construction with concentration of pressure.

This will be the basis for the further development of small hydropower. Small hydroelectric power plants have a positive effect on the operation of the grid. They provide an opportunity to generate electricity at peak loadings and accumulate water in reservoirs with excess power in the grid, i.e. to be an active participant in the balancing segment of the market. In order to reduce the cost of production of electric energy at small hydroelectric power stations, automation of their management is carried out [16]. The priority of state policy should be not only to increase the percentage of use of hydropower potential of rivers, but also to implement the principles of integrated river basin management, taking into account ecosystem services of rivers, in order to ensure the conditions for their saving and restoration.

World experience shows, that the economic and environmental efficiency of small hydropower has a period of rapid growth. In recent years there has been a resurgence of interest in the development and use of small hydroelectric power stations. In most countries, they are being built on a new, more advanced technical basis, inter alia, with complete automation of their work and remote control [4].

A project of the United Energy System Ukraine Development Plan for 2016-2025, developed by the state-owned enterprise National Energy Company Ukrenergo, foresees, for the period up to 2025, an increase in new producing capacities at small hydroelectric power plants of Ukraine to $67.8 \mathrm{MW}$, in particular, of them in Carpathian region to $56.93 \mathrm{MW}$, which will amount to $84 \%$ of the total capacity. It is planned to build 19 small HEPS, of which 5 small HEPS with a capacity of $28.0 \mathrm{MW}$ in the Zakarpatska region, 7 small HEPS in the Lviv region with a capacity of $15.9 \mathrm{MW}$, in Ivano-Frankivsk region 2 small HEPS with a capacity of $0.9 \mathrm{MW}$ and in Chernivtsi region 5 small HEPS with capacity of 2, $13 \mathrm{MW}$ [1].

Using the hydropotential of small rivers in Ukraine can achieve significant savings in fuel and energy resources, and the development of small hydropower will contribute to the 
decentralization of the overall energy system, rather than solve a number of problems in the supply of remote and hard-to-reach areas of the countryside. Micro, mini- and small-scale hydroelectric power stations can become a powerful basis for energy supply for all regions of Western Ukraine, and for some regions of the Zakarpatska and Chernivtsi regions - a source of complete energy supply [11].

The power industry of any state is the foundation and an important part of the national economy, which is primarily connected with the production and maintenance of the needs of the society in electric and thermal energy. Undeniably, at the present stage of human development, electricity is the basis and an integral part of not only modern industrial production, agriculture and science, but also a habitual and integral part of our everyday life.

\subsection{Legal regulation of the development of small hydropower}

Today, the energy policy of Ukraine is aimed at energy saving and the development of renewable energy sources. One of the priority tasks and directions of the implementation of the energy strategy is the development of the energy legislation of Ukraine. Any economic, institutional and other transformations in the energy sector as well as the construction of domestic and foreign policy in this area should be based exclusively on the provisions of the laws of Ukraine.

The legal principles of functioning of the small hydropower market and the formation of relations related to the production and supply of electricity are regulated by the Law of Ukraine "On the Electricity Market" [18], the Law of Ukraine "On Alternative Energy Sources" [19], the Law of Ukraine "On Electric Power Industry "[20], and other legislative acts in the field of fuel and energy complex. These laws should become the basis of legal regulation of energy relations. Such regulation should be as clear and precise as possible, which will minimize the adoption of by-laws and avoid the discriminatory application of legislation [21].

Small hydropower of Ukraine is important not only at the national level, it has an international dimension, in particular, in terms of improving energy security in Europe and combating climate change. Therefore, it is important that the strategic, political and legislative guidelines of Ukraine also take these objectives into account and take them into account when implementing all the state and local energy policies and policies for the development of each single small hydropower project. It is necessary to consider that the production of hydropower is not absolutely ecologically safe and can create a number of problems that need to be addressed within the framework of international as well as national law.

Accordingly, bilateral agreements are the main regulators of relations related to the production of hydropower. Agreements on the functioning and development of hydropower, one of which is Ukraine, contain different norms on this issue.

Thus, in the Framework Convention on the Protection and Sustainable Development of the Zakarpatya, the parties agreed to take appropriate measures to include the goals of conservation and sustainable use of biological and landscape diversity in the country's energy policy in the region. Developing programs and policies for spatial planning, states must pay particular attention to energy. The Parties are pursuing policies aimed at introducing environmentally sound methods of production, distribution and use of energy that reduce the adverse impact on biodiversity and landscapes, including wider use of renewable energy and energy saving technologies when needed [22].

Under the agreement with Slovakia on border waters (1994), it is provided that the protection and use of border waters can only be carried out through close cooperation, water management issues at border waters to be decided on the basis of good neighborliness and 
mutual benefit for the purpose of rational water use, water resources conservation, environmental protection [23].

The Agreement with Moldova (1994) stipulates that the distribution of water resources of frontier water bodies shall be established in the schemes approved by the Contracting Parties for integrated use and protection of water resources, operating rules, water balance basins of border water bodies or in the Convention. Each Party independently develops water management projects on the border waters on its territory, which are agreed upon between the Parties. If one of the Parties wishes to entrust the execution of the design work to the other Contracting Party, performance thereof shall be carried out in a separate agreement or contract [24].

The agreement with Belarus (2001) stipulates that the parties are obliged to use transboundary waters in their territories, without worsening the conditions of water management in the territory of the other Party. The Parties undertake to cooperate in the development of general water management plans, to coordinate water management and water protection measures in transboundary waters, and to assist each other in their implementation [25].

In addition, many agreements and the Convention provide for the establishment of joint watercourse management bodies. Such bodies have a wide range of tasks, including regulating issues of hydropower production.

It should be noted that currently the legislative regulation and state management of electricity in Ukraine are not sufficiently effective. For the development and operation of small hydropower, it is necessary to provide favorable conditions for investment at the legislative level. The state should also support the development and implementation of competitive technologies and the provision of modern equipment. Such events will form the basis for further reducing the cost of building stations and expanding the use of energy for small years.

According to the results of the audit of the Accounting Chamber and the analysis conducted, it was established that the legal regulation of the issues of the development of hydropower engineering remained inadequate. Implementation of measures for the development of small hydropower although it is foreseen in the strategic documents as a priority, but specific sources and mechanisms for raising funds for their financing are not defined. Government and sectoral programs for small hydropower development need to be improved.

\section{Conclusions}

Summarizing the results of the study, one can distinguish the following key positions in the development of small hydropower energy:

- the share of small hydropower in the total installed capacity of renewable energy objects remains insignificant, but the natural potential of its development is not yet fully realized;

- the "green" tariff has led to an increase in the number of producing installations, installed capacities and electricity producing by small hydroelectric power plants;

- dynamic and timely adoption of state programs, national action plans, etc., determine the strategic framework for the development of small hydropower as an element of renewable, alternative energy;

- to address the issues of small hydropower development, Ukraine has sufficient scientific and technical capabilities and considerable experience in the field of hydropower potential research, hydroelectric power plant design and exploitation;

- further development of small hydropower should be carried out on a new, more advanced technical basis, connected with complete automation of their work and remote control. 
- legal, economic and organizational principles of development of small hydropower are regulated by the Laws of Ukraine and other legislative acts in the field of fuel and energy complex. However, legislative regulation and public administration of small energy in Ukraine are currently not sufficiently effective.

\section{References}

1. V. Vovchak, O. Teslenko, O. Samchenko Small hydropower of Ukraine. Institute of Ecology and Energy Conservation Problems of Ukraine Hydroenergy, Volume I, Analytical Review. Kiev 181 p. (2018) http://energyukraine.org/wpcontent/uploads/2018/05/Otchet-MGES1.pdf

2. R. B. Gavryliuk, G. K. Verimichik and others. Hydropower potential of the rivers of Ukraine: dissipation of myths: analytical document / - Kiev: Phoenix Publishing House 32 p. (2018) http://necu.org.ua/hidroenerhetychnyy-potentsial-richok-ukrayinyrozvinchannya-mifiv/

3. V. Vovchak, O. Teslenko, O. Samchenko Technological peculiarities of small hydropower plants. The Institute of Ecology and Energy Conservation Problems is the small hydropower of Ukraine, Volume II. Kyiv, 145 p. (2018) http://energyukraine.org/wp-content/uploads/2018/05/Otchet-MGES2.pdf

4. Status and prospects for small hydropower, solar, wind and other sources of renewable energy from foreign countries and Ukraine IRENA "renewable energy statistics 2016" https://ua.energy/wp-content/uploads/2018/01/4.-Stan -i-viable-rozvytku-PDE.pdf

5. Report on the results of the activities of the National Commission that performs state regulation in the fields of energy and utilities in 2017, March 23 (2018) http://www.nerc.gov.ua/data/filearch/Catalog3/Richnyi_zvit_2017.pdf

6. Information on objects of alternative energy, which has a "green" tariff. (as of 01.01.2018)

http://www.nerc.gov.ua/data/filearch/elektro/energo_pidpryemstva/stat_info_zelenyi_t aryf/2017/stat_zelenyi-taryf.12-2017.pdf

7. Oliynyk Y.M., Shafarenko Y.A., Magazine "Ecology of Enterprises", № 6 (71), p. 12 17 (2018) http://ecolog-ua.com/articles/chogo-ochikuvaty-vid-podalshogo-rozvytkurynku-elektrychnoyi-energiyi-z-vidnovlyuvanyh

8. Is there a future in small hydropower industry (July 2, 2008 08:25 ...) https://biz.censor.net.ua/columns/3074144/chi_mayibutn_u_malo_gdroenergetiki

9. Facts only: how hydropower develops in Europe - Group ... http://rener.com.ua/news/325

10. O. Kucher, L. Prokopchuk The Development of the Market of Renewable Energy in Ukraine. Renewable Energy Sources: Engineering, Technology, Innovation. Springer International Publishing AG, ISSN 2352-2542 (electronic), ISSN 2352-2534. pp. 71-82 (2018)

11. Hydroenergy of State Energy Efficiency of Ukraine http://saee.gov.ua/en/ae/hydroenergy

12. Kucher, O., Hutsol, T., Zavalniuk K. Marketing Strategies and Projections of the Renewable Energy Market in Ukraine. Scientific achievements in agricultural engineering, agronomy and veterinary medicine. Krakow, Poland, pp. 100-121. (2017)

13. All-Ukrainian forum on small HEPS: what scientists 
14. Levin G. Small hydropower of Ukraine 2018 Brief overview of the state of Ukraine on the basic principles of development of small hydropower. Part I: (2018) http://energyukraine.org/wp-content/uploads/2018/05/Oglyad-zak-va_MGE_2018 chastyna-1.pdf

15. The National Renewable Energy Action Plan for the period up to 2020. http://zakon2.rada.gov.ua/laws/show/902-2014-\%D1\%80

16. "Application of small hydroelectric power stations to provide power reserve at peak time" 2017/2018 http://events.pstu.edu/

17. S. Zabolotnyy, M. Melnyk The Financial Efficiency of Biogas Stations in Poland. Renewable Energy Sources: Engineering, Technology, Innovation. Springer International Publishing AG, ISSN 2352-2542 (electronic), ISSN 2352-2534. pp. 83-93 (2018)

18. Law of Ukraine "On the Electricity Market" dated April 13, 2017 No. 2019-VIII ..... https://zakon.rada.gov.ua/laws/show/2019-19 2019

19. The Law of Ukraine "On Alternative Energy Sources" (Bulletin of the Verkhovna Rada of Ukraine (VVR), 2003, No. 24, p.155) https://zakon.rada.gov.ua/laws/show/555-15

20. The Law of Ukraine "On Electric Power" No. 575/97-VR of 16.10.1997 https://zakon.rada.gov.ua/laws/show/575/97-\%D0\%B2\%D1\%80

21. Legislative and regulatory framework | Increasing energy efficiency in .... http://www.reee.org.ua/policy-support/legislation/

22. Framework Convention on the Protection and Sustainable Development of the Zakarpatya [Electronic resource]. - Mode of access: (2014) http://zakon4.rada.gov.ua/laws/show/998_164

23. Agreement between the Government of Ukraine and the Government of the Slovak Republic on water management at the border waters https://zakon4.rada.gov.ua/laws/show/703_061 (1995)

24. Agreement between the Government of Ukraine and the Government of the Republic of Moldova on the joint use and protection of the boundary waters https://zakon4.rada.gov.ua/laws/show/498_051 (1994)

25. Agreement between the Cabinet of Ministers of Ukraine and the Government of the Republic of Belarus on the joint use and protection of transboundary waters https://zakon.rada.gov.ua/laws/show/112_031 (2002) 